\title{
"Som hipster a neviem o tom" Pátranie po príznakových estetických hodnotách hipsterstva
}

\author{
Michaela Malíčková
}

DOI: 10.21104/CL.2019.1.03

'I am a hipster, and I don't know about it': Searching for the Marked Aesthetic Values of Hipsterhood

\begin{abstract}
The media studies vocabulary has included the word hipster in multiple ways recently and named thus seemingly unrelated phenomena. Our focus is on what puts together this diversity, and to what extent this rhetoric responds to the existing hipster values system that is more a life feeling than style or subculture. The dynamics between life style and subculture identity, dissolution of strong subcultures to tribes, scenes, and so on, or the doubt - denial even - of subculture identity are the motives that hipsterhood implicitly thematizes in the way of its cultural presentation and semantic sedimentation. We are interested mainly in existential semantics of hipsterhood as a life feeling with the stress on its aesthetic qualities, the questioning of the perception of hipsterhood - dissolving semantics of the concept and unclear semantics of the phenomenon that oscillates between a worldview, life style and fashionable trend. Methodological key to the understanding will be the interpretation of tension between the values defined by the dynamics of contradiction.
\end{abstract}

\section{Key words}

subculture, self-expression in subculture, hipster, dandy, cultural memory, irony

\section{Acknowledgment}

Príspevok je výstupom v rámci projektu VEGA č. 1/0461/16 Re-interpretácia obrazov kultúrnej pamäti v súčasnej estetickej a umeleckej reflexii.

\section{Contact}

doc. PhDr. Michaela Malíčková, Ph.D., Ústav literárnej a umeleckej komunikácie, Filozofická fakulta Univerzita Konštantína Filozofa v Nitre, Štefánikova 67, 94974 Nitra, Slovak Republic; e-mail: mmalickova@ukf.sk.

\section{Jak citovat / How to cite}

Malíčková, Michaela. (2019). „Som hipster a neviem o tom.“ Pátranie po príznakových estetických hodnotách hipsterstva. Český lid 106, 49-67. doi:http://dx.doi.org/10.21104/CL.2019.1.03 


\section{Motivácia}

Písat' o nejakom kultúrnom fenoméne v čase, ked' všetko nasvedčuje tomu, že svoje vrcholy má už za sebou, sa môže javit' ako zbytočná investícia pozornosti. V prospech mlčania hovorí aj množstvo už existujúcich relevantných výpovedí, ktoré daný fenomén predstavujú v rôznych perspektívach a preverujú ho rôznymi metodológiami. Ja však aj napriek tomu stále považujem hipsterstvo za výzvu a mám potrebu artikulovat' problematické miesta tejto subkultúrnej identity ako prioritne estetického fenoménu, teda pokúsit' sa uchopit' „nepolapitel'né“, lebo práve oná neuchopitel'nost' sa často javí ako jediné pozitívne vymedzenie. Ambíciou môjho preverovania je preto identifikovat' hipsterovo aktuálne miesto v kultúrnej pamäti ${ }^{1} \mathrm{v}$ možných pozitívnych väzbách na tie elementy kultúrnej tradície, ktoré fungujú ukotvujúco, a čo najpresnejšie pomenovat' tie kvality, ktoré aj napriek permanentným obsahovým zmenám hipsterského kódu vystihujú jeho integritu.

\section{Teoretické východiská}

Názov textu odkazuje k aktuálne nejasnému až zavádzajúcemu obrazu hipstera, ktorého sémantika sa v závislosti od pomerne dynamickej a vd'aka tomu rozplývavej semiotike pohybuje medzi subkultúrnou identitou, životným štýlom kreatívnej spoločenskej elity a módnym trendom rozpoznatel'ným v mainstreame. ${ }^{2}$ Tieto tri pozície reprezentujú možné synchrónne sa vyskytujúce podoby hipstera v súčasnej spoločnosti a zároveň môžu byt' interpretované ako tri vývojové štádiá, ktoré fungujú zástupne ako univerzálne platný model životnej dynamiky akejkolvvek subkultúry. ${ }^{3}$ Pre spôsob existencie subkultúry je definujúce, že povaha kultúry je vo svojej prirodzenej podstate dialogická, ako to identifikuje Jurij Lotman (1994) vo svojej koncepcii rozvíjajúcej Bachtinovu ideu dialogizmu ako podmieňujúcej vlastnosti každej výpovede. Nehomogénny celok kultúry (vždy minimálne dvojkanálový) a jej podsystémy

1 Termín kultúrna pamät používame v sémantickej blízkosti konceptu Aleidy a Jana Assmannovcov. Pozri napr. Assmann 2001.

2 Tieto tri pozície navzájom od seba odlišuje miera trvácnosti, komplexnosti, zvnútornenia, ako aj prítomnost' svetonázorovej perspektívy a potreba zdiel'at' svoju výnimočnost' s ostatnými.

3 Vývojovej dynamike a sebavýrazu sa ako interpretačným nástrojom porozumenia subkultúram venujem aj v predošlom výskume (pozri Malíčková 2015), nadväzujúcom na výskum tínedžerskej kultúry, ktorému sa Ústav literárnej a umeleckej komunikácie v Nitre venoval v polovici 90. rokov 20. storočia (pozri napr. Šabík 1996). 
navzájom komunikujú a ich vzájomný vztah charakterizujú dynamika, napätie, vývoj. V tomto zmysle je narúšanie existujúceho dominantného kultúrneho poriadku želatel'né až žiaduce, aby sa zamedzilo stagnácii, regresu. Hoci pre konkrétne subkultúry môže byt' výmena informácií likvidačná (kolonizácia okraju mainstreamom, vyprázdňovanie pôvodných významov, formalizácia a následne zánik alebo subkultúrne redefinovanie), pre kultúru ako celok je regeneračná. Dôsledkom tejto dynamiky je aj rozpúštanie sa hipstera v mainstreame, strata jasných kontúr kmeňovej identity (možno skôr, ako sa naplno sformovala). Kompatibilne popisujú tento mechanizmus aj Joseph Heath a Andrew Potter v knihe Kup si svou revoltu (2012), len túto dynamiku vzájomného vplyvu interpretujú v optike spotrebného správania a konzumu: túžbu odlíšit sa identifikujú ako univerzálnu motiváciu, vd'aka ktorej si dominantná kultúra osvojuje znaky subkultúr, a to často práve obstarávaním materiálnych statkov symbolicky reprezentujúcich odlišnost' a s tým spojený spoločenský status. Mám však za to, že tento popis zohl'adňuje len parciálne motívy v jednosmernej logike, a preto bude pre estetickú identifikáciu subkultúrnej identity prínosnejšie vrátit' sa k lotmanovsko-bachtinovskému diskurzu a pýtat' sa: čo je príznakové pre dialóg medzi jednotlivými kultúrnymi kanálmi? Bezpochyby to, že dialóg medzi dominantnou kultúrou a subkultúrou je obojsmerný a prebieha na osi binárnych opozícií:

- my/naše - vy/oni, vaše/ich

- insider-outsider

- svoje-cudzie.

Poslednú z nich považujem v optike existenciálneho ukotvenia problematiky subkultúr za najvýstižnejšiu ${ }^{4}$ a subkultúrny sebavýraz prezrádza, čo aktuálne (časopriestorové súradnice pobytu tu a teraz), a aj v kultúrnej tradícii (časopriestorové kotvy v kultúrnej pamäti) považuje jeho reprezentant za svoje a čo za cudzie.

Klúčová opozícia svoje - cudzie následne usmerňuje d'alšie čítanie hipsterstva ako člena nehomogénneho systému kultúry, ktorý sa vymedzuje voči dominantnej kultúre (mainstreamovej), koncentrovanej okolo spoločenského stredu, hodnotovo tradičnej až konzervatívnej. Hipster je zaujímavý svojím špecifickým narábaním s opozíciou svoje - cudzie, resp. s premenou cudzieho na svoje, pretože hoci po cudzom siaha programovo, odmieta ho urobit' svojím v plnej miere, čoho dôsledkom je demonštrovaná irónia.

4 V širšom filozofickom rámci ukotvujem kategóriu svoje - cudzie v takom sémantickom prostredí, ktoré je blízke napr. Bernhardovi Waldenfelsovi v Znepokojivé zkušenosti cizího, 1998. 
Subkultúrnu estetiku hipsterov preverujem v širších súvislostiach s ciel'om porozumiet' spôsobu existencie komunity, resp. jej členov, pričom semiotické intertextuálne čítanie je tu metodologickou paradigmou. Takéto čítanie umožňuje aj fakt, že subkultúry často markantne transponujú svoju subkultúrnu identitu do štýlu. Ten má v prípade subkultúr, ako pripomína Dick Hebdige (2012: 26-27), subverzívnu hodnotu a predmety (veci, znaky) ním používané nadobúdajú symbolický potenciál, teda majú dvojakú validitu. Sú upozornením, výstrahou pre bežný svet a zvýznamňujú sa ako znaky odlíšenej identity a prerušenia procesu normalizácie pre členov jednotlivých subkultúr. Hipsterská irónia - postoj definujúci toto „společenství stylu“ (Daniel - Ǩídký 2017: 322) - je pointou práve potenciálne dvojitej validity znakov.

Štýl subkultúry je výpoved'ou, systémom znakov a ich výrazových kvalít, ktoré sa transponujú do subkultúrneho sebavýrazu - „súhrnu typických výrazových stránok, ktorými človek (skupina) odkrýva vlastnú totožnost' a chápanie skutočnosti“ (Plesník a kol. 2008: 45). Do vel'kej miery je výsledkom procesu sebauvedomovania, sebavnímania a sebadefinovania, ale taktiež sa na ňom podielajú prvky spontánnosti a neuvedomelosti. Preto sa môže stat', že isté kultúrne pohyby začnú byt vnímané ako subkultúrne najprv zvonka, a práve táto identifikácia napomáha následnému profilovaniu skupinovej, resp. subkultúrnej identity, prípadne $\mathrm{k}$ jej odmietaniu (ako práve v prípade hipsterov).

Kvality definujúce sebavýraz môžeme interpretovat' $\mathrm{v}$ dvoch tendenciách:

- ako znaky, ktoré člena subkultúry definujú, identifikujú so sebou samým;

- ako znaky, ktorými sa člen subkultúry definuje smerom von, voči ostatným členom subkultúry aj voči tým mimo nej. Tieto znaky sú zväčša evidovatel'nejšie a často sa práve s nimi narába pri tvorbe mediálnych obrazov, ktoré fungujú ako relevantná informácia o tom, ako sa daná subkultúra smerom von javí a ako je spoločensky vnímaná, vrátane rizík dezinterpretácie signalizujúcej často predsudkový postoj mimosubkultúrnej väčšiny.

Dynamika subkultúrnej sémantizácie nás vedie do centra vzt'ahu autentického a štylizácie. Pokial' Erich Mistrík upozorňuje v súvislosti s autenticitou predovšetkým na úprimnost', pravost' (Plesník a kol. 2008: 54), v mojej optike sa zviditelňuje skôr presvedčivost', hodnovernost' a hlavne individuálne ako najvyššia hodnota autentického. Autentické sa viaže na spontánnost', teda minimálne podlieha korekcii a štylizácii. Prirodzené autority však dokážu ja menit na subkultúrne $m y$, čo síce oslabuje individuálnost' a spontánnost', ale vo vzt'ahu k oni posilňuje jedinečnost'. Mnohé pôvodné, autentické prejavy sa 
v tomto procese transformácie ja na my stávajú vzorom, až vzorcom skupinového vyjadrenia a $\mathrm{v}$ štylizáciách sa menia na príznačné.

Subkultúrny sebarýraz, ako vyjadrenie postoja, funguje ako špecifický kultúrny kód, ktorý nám pomôže porozumiet jednotlivým subkultúrnym prejavom (habitu, väzbe na priestor atd'.) práve prostredníctvom vztahu $\mathrm{k}$ autentickému a štylizovanému, jedinečnému a príznačnému, individuálnemu a skupinovému.

\section{Mediálny obraz súčasného hipstera}

Hipstera považujem za reprezentatívny príklad postmodernej subkultúrnej identity (či za príznakovú identitu baumannovskej tekutej modernity - Baumann 1995; 2002) z viacerých dôvodov, ktoré môžem predbežne zhrnút do štyroch okruhov:

- pochybnost' o existencii subkultúry - rozplývavé hranice subkultúrnej identity;

- dôraz na individualizmus;

- estetizácia životného štýlu ako forma spoločenskej angažovanosti;

- ironický postoj k svetu ako demonštratívne vyjadrenie nedôvery, odstupu. ${ }^{5}$

Pre mňa ako outsidera je prirodzenou cestou k dekódovaniu hipsterskej estetiky prenikanie zvonka. Relevantné odpovede budem preto $\mathrm{v}$ prvom pláne hl'adat' v rôznych mediálnych obrazoch subkultúry, či už ide o komentovanie printových médií, reklamu alebo modelovanie obrazu hipstera v TV seriáloch a podobne. Kvôli možnému napätiu medzi dekódovaním vo vnútri subkultúry a mimo nej ma však vždy bude zaujímat', čo je za týmto mediálnym obrazom a ako sa môže stat' zrozumitel'ným vd'aka stopám v kultúrnej pamäti, na ktoré nás on sám navádza. Ako som už uviedla, semiotické intertextuálne čítanie je tu metodologickou paradigmou. Mediálne obrazy, či už z prostredia inside alebo outside, sú v tejto výkladovej perspektíve textami kultúry, ktorým môžeme porozumiet' len v procese dekódovania znakov, ktorými sú vytvárané. Mediálne obrazy vznikajúce

5 Sústred'ujem sa na tie príznaky identity tekutej modernity, ktoré sa opakovane objavujú v rozmanitých charakteristikách postmoderny. Počnúc Ihabom Hassanom (napr. The Postmodern Turn: Essays in Postmodern Theory and Culture, 1987) cez Wolfganga Welscha (napr. v Estetickom myslení, 1993), Stanislava Hubíka (v texte Postmoderná kultúra. Úvod do problematiky, 1991) až k Tiborovi Žilkovi (napr. v Postmodernej semiotike textu, 2000) sa upozorňuje na rozplývavú sémantizáciu znaku, nestálu identitu bez pevného jadra, ironizáciu a individualizmus ako dôsledky rezignácie na univerzálne platný koncept pravdy. 
mimo subkultúru, ako jej reflexia zvonka, fungujú ako relevantné výpovede o tom, ako je daná komunita vnímaná, aké konvencie a stereotypy sa na ňu nabal'ujú, ktoré sama posilňuje či vytvára. Tieto mediálne obrazy samé často pomenúvajú napätie, ktoré môže vznikat medzi rôznymi typmi obrazov alebo obrazmi a ich možnými interpretáciami. Sú cennými dôkazmi procesu kultúrneho usádzania subkultúry.

Ako teda používa termíny hipster/hipsterský mediálna rétorika? Ako sa prostredníctvom toho či v konfrontácii s tým dá rozumiet' hipsterovi a jeho životnému štýlu a aké kultúrne fenomény sú s hipsterstvom stotožňované?

Publicistika obvykle vnáša do správ a reportáží o aktuálnom stave hipsterstva hodnotiaci tón, ktorý je, podobne ako hipster sám, zväčša ironický. Iróniu podsúva ako recepčný kód pre svoj Praktický slovníček bratislavského hipstera blogerka Michaela Istok (2013) alebo Martina Overstreet v článku pre ELLE (2017) a v oboch textoch cítime prítomnost' zlahka sympatizujúceho autora, azda aj kompetenciu čiastočného insidera. Ojedinele sa objavujú aj pozitívne naladené, miestami obranné výpovede v mene všetkého zmysluplného, čo hipsteri vrátili do kultúrnej pozornosti, napriek tomu, že tých skutočných už takmer niet (Bollason 2012; Kapusta 2012; Tracy 2017). Nie výnimočne sa hipster ocitá na pranieri, rétorika je výsmešná, postoj až odmietavý a výhrady sa zväčša týkajú podozrenia z vyprázdnenosti, predstierania, pozérstva. Naprieč blogmi, kultivovanou publicistikou aj serióznejším odborným výskumom býva hipster charakterizovaný ako konzument marketizovanej indie kultúry, ktorý svoj vkus nadrad'uje vkusu väčšiny, opak trendsettera, ktorý vyznáva náboženstvo up-to date, napíňa ho však len formálne bez skutočnej posadnutosti novým, je bez vlastnej scény, je komunitou hypu: príchodu - odchodu (Havlín 2012b). V lepšom prípade býva ospravedlnený ako diagnóza doby, ktorú vystihuje neautentickost', spotreba a kríza angažovanosti (Veselý 2012b), v horšom prípade býva vnímaný pejoratívne, ako nadávka, ktorou hodnotíme neautentických l'udí s mylným hodnotiacim súdom (Havlín 2012a; Veselý 2012a). Hipster je v posledných rokoch často identifikovaný ako prekonaný, prežitý model životného štýlu (Veselý 2012a, b; Biler 2015), je spájaný so statusom dôchodcu, bývalého trendsettera vo výslužbe (Havlín 2012b). Hipster je kultúrou, ktorá vytvára len zdanie svojej existencie (Veselý 2012b). Hipster ako zostatkový obraz. Dokonca ako simulakrum (Daniel - Ŕídký 2017), ked'že súčastou mediálneho obrazu hipstera je aj jeho úplné popieranie, ktoré vychádza tak zvnútra identifikovanej komunity (Veselý 2012a), ako aj zvonka: hipster je len módny trend, hipster je mýtickou rasou, je projekciou „nehipstera“, ktorá slúži ako bezpečný nástroj kultúrnej kritiky (Feranec 2015). Neexistuje a predsa sú dôsledky jeho pôsobenia zretel'né. 
V kultúrnom priestore sa tak zjavne máme možnost' stretnút' so všetkým od pozitívnej identifikácie subkultúry s opatrným, podozrievavým či negatívnym hodnotením jej prejavov až po negovanie jej existencie. Jej opakované tematizovanie v mediálnom priestore však potvrdzuje, a to je dôležité a usvedčujúce, že existuje povedomie o kultúrnom fenoméne, ktorý vykazuje registrovatel'né spoločné znaky a má viditel'ný vplyv na celkový kultúrny obraz. Rozporuplnost', ambivalentnost' tohto kultúrneho fenoménu, či už má rozmer módneho trendu, kmeňového združovania alebo subkultúneho pohybu, je jeho výnimočne koncentrovanou esenciálnou vlastnostou a aj preto ho považujem za príznakový pre globalizovanú a pritom silne individualizovanú tekutú modernitu 21. storočia.

Reklama, samozrejme s ohl'adom na zvoleného cielového zákazníka, využíva aktuálne živý obraz hipstera so všetkými jeho dosial' usadenými konvenciami. Jednoduchá obchodná rétorika využíva hipstera zväčša vo väzbe na pozitívnu sémantiku, v ktorej je hipsterské spájané so správnou vol'bou, s tým, čo je „in“. Výpovednejšia je však taká reklamná stratégia, ktorá využíva jeho komplexnú sémantiku a hodnotovú ambivalenciu. Popradská káva napríklad spustila v roku 2015 kampaň Popradská káva: Praví kávičckári, ktorú tvorí séria štyroch reklám, akýchsi troch fiktívnych prípadových štúdií (Hipsteri pijú Popradskú https://www.youtube.com/watch?v=bVDfjMtSWtU, Čajočky pijú Popradskú, Manažeri pijú Popradskú) a jedného prieskumu v uliciach (Taliani pijú Popradskú). Každá z oslovených skupín iným spôsobom reprezentuje kávičkárov-znalcov, ktorí počas degustácie Popradskej kávy Extra špeciál v troch fingovaných verziách potvrdia kvalitu kávy a spolu s tým svoju predpojatost', či dokonca nekompetentnost'. Traja hipsteri degustujú Ferovu kávu (evokuje férovú v zmysle fair traid), Poctivú kávu od deda (odkazuje k tradícii a poctivému remeslu) a Urban Hype Coffee (reprezentuje akýsi estetický ideál, symbol mestského životného štýlu hipstera) a komentujú ich slovami, ktoré prezrádzajú viac o nich než o káve: oceňujú poctivost', férovost', lokálnost', ručnú prácu, remeslo, tradíciu, štýl a kreativitu, potvrdzujú dôležitost' mediálneho obrazu a samozrejmú prítomnost' moderných technológií. V zhode so zvyšnými reklamnými spotmi vystupujú ako tí, ktorí viac predstierajú, než skutočne vedia, sú skôr pozérmi než znalcami. Imidž, s ktorým pred diváka predstupujú, je príznakový: bradatí muži s vekom medzi dvadsat' až tridsat rokov, dvaja v okuliaroch s tmavými hrubými rámami, jednému vytŕča spod saka kockovaná košel'a, bradu aj vlasy má upravené v dokonalom strihu, druhý má vol'ný pletený retro pulóver podobný tým, ktoré plietli matky svojim detom v 70. či 80 . rokoch minulého storočia a ten tretí kultivuje alúziu na 
pracovný odev šik klobúkom. Sú subkultúrne identifikovatel'ní a predsa je aj každý sám za seba (hoci zároveň reprezentuje aj jeden z možných typov). Pre hipstera je vyjadrenie dištinkcie prostredníctvom odevu dôležité, preto snorí v second-handoch, revitalizuje a recykluje odevy svojich rodičov či vlastnej rannej mladosti, je fanúšikom retra a vintage nostalgie, povyšuje pracovný odev na formálny a naopak, prípadne sám pridá ruku k dielu, všetko preto, aby preveril mieru konfrontáciou protikladov. Azda aj preto, že často narába s pomerne konvenčnými a dostupnými jednotkami, je hipsterský kostým pomerne l'ahko napodobnitel'ný a úspešne sa vstrebáva ako módny trend do mainstreamu.

O subkultúrnom odeve, teda o subkultúrnej móde budem najpresnejšie hovorit' vtedy, ak ju usúvztažním s módou v perspektíve, v akej o nej uvažuje Gilles Lipovetsky, teda ako fenoméne spojenom s rozvojom moderného západného sveta. Móda v demokratických spoločnostiach je podl'a neho dôkazom individualistických tendenciú, autonómnej subjektivity (Lipovetsky 2002: 12-26, 55-68). Móda pôvodne fungovala ako sociálne kastovný systém, pričom v demokratických spoločnostiach na túto úlohu do vel'kej miery rezignuje. Nazdávam sa však, že v subkultúrnom odeve sa opät posilňuje jeho funkcia semiotického kastovného systému - tentoraz však dobrovolného. Binárne opozície, ktoré ho definujú, sa konkretizujú predovšetkým do dvojíc:

- autentické - stylizované

- odlišujúce - imitačné

- osobité - uniformné.

Práve blízkost' či vzdialenost' uniformovanému odevu je dôležitým recepčným signálom. Väčšina subkultúrnych odevov má spoločné charakteristické prvky, ale nie každý z nich môže byt' čítaný ako uniforma. Uniformita subkultúrneho odevu je závislá od miery osobitého, individuálneho v príznakovom a táto miera zároveň vypovedá aj o povahe vnútornej štruktúry subkultúry a o postavení jedinca v nej, o miere ideologizácie životnej filozofie a pod. Pokial' napríklad odev skinheada je uniformný (radikálne, ak ide o skinheada-neonacistu), odev hipstera dbá na individualizačné prvky, ale nerezignuje na spoločné prvky, ktoré zabezpečujú zretel'nú príslušnost' ku komunite.

Americký animovaný seriál Simpsonovci dlhodobo funguje ako popkultúrny pastiš schopný pointujúco vykreslit' charakter aktuálne dobovo rezonujúcich kultúrnych a spoločenských fenoménov či politických udalostí. Dokáže rozpoznat príznakové kvality tematizovaného fenoménu a efektívne ich využíva pri vytváraní hyperbolizovaného obrazu ironicky narábajúceho s konvenciami, stereotypmi a klišé, ktoré po čase do všetkých obrazov (vd'aka mechanizmom opakovania) prirodzene prenikajú alebo sa 
priamo v nich generujú a práve oni ukazujú na to, čo sa smerom von javí ako charakteristické. ${ }^{6}$

Kritickému drobnohl'adu seriálových tvorcov neušiel ani hipster a v roku 2012 bola odvysielaná siedma epizóda dvadsiatej štvrtej série s názvom The Day the Earth Stood Cool, do češtiny preložená bez sémantickej vrstevnatosti slova cool ako Den, kdy se země ochladila. V rétorickom zveličení pre seriál typickom dostávame mediálny obraz hipstera - frajera: osobnost', individualitu, ktorá sa úplne prirodzene združuje s jemu podobnými vyznávačmi originality, pôvodnosti, prirodzenosti, zdravého eko/bio života, zabalených do osobitého štýlu, ktorý je schopný atraktívne spojit' staré s ultra moderným, pričom sa nikdy neuspokojuje s dosiahnutým stavom a jeho permanentná honba za autentickým, ktorú potrebuje demonštrovat', ho paradoxne prevracia na svoj opak a definuje v očiach mimosubkultúrnej väčšiny ako smiešneho pozéra. Akokolvek je tón Simpsonovcov kritický, rétoricky ironický a v naračnom konflikte potvrdzuje tradičné neporozumenie medzi alternatívou a mainstreamom, subkultúrou a dominantou, vieme, že hipstera nepranieruje, dokonca ho v záverečnej scéne - ked' Líza (ako pozitívna seriálová figúra) neštastne uteká za kolónou presídlujúcich sa hispterov, lebo Springfiled prestal byt' cool miestom na život - omilostujue.

\section{Hip ako cool. Obraz pôvodného hipstera}

Hipster nás terminologicky odkazuje na subkultúru z polovice 20. storočia. Na prvý pohl'ad môže byt' táto stopa považovaná za zavádzajúcu a väzba medzi hipstermi vzdialenými niekol'ko desat'ročí za natol'ko vol'nú, až sa môže zdat' ako nepresvedčivá, umelá či dokonca mylná. Pri preverovaní príznakových kvalít hipstera 50. rokov však v niekol'kých vrstvách naopak nachádzam bazálnu príbuznost' s definujúcimi znakmi toho aktuálneho. Sprítomnenie pôvodného hipstera sa tak pre porozumenie súčasnému hipsterovi stáva relevantnou požiadavkou.

Hippie encyklopédia uvádza pri hesle hip, že ide o to byt' v obraze, informovaný, vediet', poznat', byt' cool (McCleary 2010: 266). O hipsterovi hovorí, že je to výraz pre cool osobu, pričom však spresňuje jeho identitu previazaním s beatníkom, s ktorým zdiel'a rovnaké existenciálne a časopriestorové súradnice i vášeň pre černošskú kultúru (McCleary 2010: 266). Napriek tejto príbuznosti však nie sú navzájom zamenitel'ní, a ako

6 V tomto zmysle nemá kultúrny text menšiu výpovednú hodnotu než odborný metatext, naopak, legitimizuje svoje miesto vo výskume zdvojeným statusom: môžeme ho vnímat' ako živú kultúrnu jednotku, teda materiál prvovýskumu a zároveň ako metatextovú udalost', teda text vypovedajúci o už existujúcom texte. 
upozorňuje Hebdige, „ačkoli hipsterská i beatnická subkultura vycházely ze sdílení černošské identity (symbolizované jazzem), povaha této identity, jak se manifestuje ve stylech obou skupin, byla kvalitativně odlišná. Fešácký oblek a lehké kontinentálky na hipsterovi zosobňovaly tradiční touhy černocha z nároží (všechno zvládnout a vyšvihnout se), zatímco beatnik, záměrně navlečený v odrbaných riflích a sandálech, vyjadřoval magický vztah k chudobě, která pro něj představovala vysněnou božskou esenci“" (Hebdige 2012: 85). Norman Mailer vo svojej štúdii pôvodného hipstera 50. rokov interpretuje jeho hip ako pripravenost' závislú od energie: „Důraz je dáván právě na energii, protože psychopat a hipster bez ní nejsou vůbec nic, nebot' nemají žádné obranné postavení nebo třídu, o kterou by se mohli opřít, když svoji sílu přecení." (Mailer 1990: 78) Hipster chce byt' pripravený - či už na príslušníka dominantnej kultúry, na slušňáka (square) alebo na d'alších ako je on sám, pretože vždy je sám za seba, teda ostražitý. Inak stráca sebadôveru, vôlu, stáva sa impotentným, teda neschopným spontánnej tvorby, improvizácie, neschopným pretavit' autentickú skúsenost' do jazyka či štýlu. Cool rebelujúceho hipstera znamená tichý individuálny dištanc, nie je vyjadrením kolektívneho odporu.

Hip, teda cool, znamená byt' inside, zasvätený, nadradený, rozumiet' a predsa nedat' najavo, že na tom záleží - teda udržat'si estetickú dištanciu. Aj napriek pozitívnemu hodnotiacemu akcentu cool vyjadruje emocionálnu zdržanlivost'. Najlepším nástrojom na to je irónia, ktorá sa rodí z pochybnosti nad reflektovaným svetom a sebadôvery pochybujúceho.

Irónia (ako zhovievavo-kritický nadhl'ad, nevážnost' a predsa zacielenost') sa stala klúčovým vyjadrovacím nástrojom hipstera, ktorému pomáha byt' vždy pripravený, vždy cool. Obsahová náplň cool sa mení v závislosti od kultúrnych kódov, v kontexte ktorých sa nachádza, preto, hoci sa dá postoj cool vnímat ako pomerne univerzálna hodnota súčasnej kultúry v mnohých subkultúrach aj v mainstreame, cool artefakty nie sú navzájom zamenitel'né, plnia svoju funkciu len v určitých kontextoch a dočasne, ich hodnota je prenosná len čiastočne a práve preto môžu symbolicky reprezentovat' istý sociálny status obmedzene a tým podporovat mechanizmy spotreby a konzumného správania, ktoré sa ako dôležité vo vztahu k subkultúram ukazujú mnohým teoretikom kultúry (Heath - Potter 2012; Klein 2000; Lipovetsky 2002; 2007).

V kultúrnej pamäti sa hipster spája s obrazom akéhosi cool flákača reprezentujúceho spoločensko-kultúrne premeny v 50. rokoch 20 . storočia. Býva vnímaný ako predstavitel' kontrakultúry, rebel, „jediný extrémní nonkonformista své doby“ (Mailer 1990: 74), hoci aj v tejto pôvodnej verzii sa vlastne len prostredníctvom dištinktívnych prvkov pokúša zmenit' svoj spoločenský status a nie rezignovat' na akýkolvek spoločenský status, ako 
pripomína aj Hebdige prostredníctvom Goldmanovho výroku „Hipster byl (...) typický dandy z nižší třídy, oblečený jako pasák, jenž se snažil působit velice pohodovým a přemýšlivým dojmem - aby se odlišil od ostatních neotesaných a impulzivních obyvatel ghetta" (Hebdige 2012: 84). Mailer ho označuje ako amerického existencialistu, ktorý sa zrodil, ked’ „bohém a mladistvý delikvent se v tváří v tvář potkal s černochem“ (Mailer 1990: 75) a v tejto charakteristike je vypointované celé subkultúrne napätie, kontradikcie koncentrované v postave „bieleho negra“, teda hipstera, ktorý „absorboval existencialistické synopse černocha“, žijúceho medzi totalitou a demokraciou, medzi stálym ponížením a stále hroziacim nebezpečenstvom, černocha, ktorý odhalil a rozpracoval morálku dna (Mailer 1990: 76). Od tohto východiskového obrazu sa súčasný hipster vzdialil radikálne, ostalo mu len hip ako cool vyjadrujúce estetický dištanc, vášeň k černošskej kultúre sa transformovala do nekonečného záujmu o inšpiratívne podnety z rôznokultúrnych chronotopov.

\section{Súčasný hipster: od odmietania subkultúrnej identity k perspektívam jej pretvárania}

Estetizácia životného priestoru ako životný program a sociálna angažovanost'

Hipster hrdo sa hlásiaci k svojej subkultúrnej identite sa v súčasnosti lahko stratí v „dave“ jemu podobných, ktorí sa súčastou žiadnej subkultúry necítia byt'. Tých dôvodov môže byt' viacero a strácanie sa kmeňovej odlišnosti v mainstreame ako dôsledok prebiehajúceho vnútrokultúrneho dialógu je len jednou z prirodzených možností. Nemenej relevantnou možnostou dištancu od kmeňovej identity sa mi javí ambivalencia vyplývajúca z permanentného napätia medzi definujúcimi protikladmi, ambivalencia, ktorá je až esenciálnou črtou hipsterského charakteru. Hipster je posadnutý novinkami, teda zmenou. Byt' pred ostatnými, vybrat' sa v pátraní po inšpiráciách iným smerom než ostatní, znamená skutočne sa líšit, byt' cool, potvrdit' svoju osobitost'. „Odlišujem sa, teda som, “ by mohla zniet' hipsterská parafráza na Descartesovo „Cogito ergo sum, “ a súhlasit' s označením, zaradením by mohlo potvrdzovat' stagnáciu, zaseknutie.

V sústredení sa na individualitu nielenže súčasný hipster potvrdzuje (napriek zrejmej diskontinuite vývoja) väzbu na svojho viac než o šest'desiat rokov staršieho predchodcu, ale pointuje dlhodobý kultúrno-spoločenský vývoj, ktorý položil základy demokratických spoločností. Individualizácia, ako ju interpretuje napríklad Lipovetsky (2002; 2007), znamená podporu jednotlivca na úkor spoločenstva, čo je podmieňujúci princíp fungovania 
princípu módy, ktorý v postmodernite prenikol do všetkých zložiek spoločnosti a spôsobil rozmelnenie životných štýlov a oslabenie subkultúr. Hoci individualizmus býva spájaný s pozitívnymi zmenami (so sebarealizáciou, emancipáciou a pod.), v poslednom období sú registrovatel'né aj patologické efekty (Chorvát 2015: 10) a prílišná sústredenost' na osobnú identitu, na sebarealizáciu, sebadefinovanie spôsobuje krízu vztahu k spoločnosti. Hipster je tak reprezentatívnym príkladom kultúrneho individualizmu a spoločenského egoizmu konfrontovaného s túžbou predsa len niekam patrit' a spoločne s niekým čosi budovat'. Zvonka nechce byt' identifikovaný ako stála jednotka väčšieho celku, pretože je sám za seba, chce rozhodovat' sám o sebe a chce byt'v pohybe. Preto v podstate vel'mi efektívne balansuje medzi seba uprednostnením a pôsobením v komunite, snaží sa na svoj obraz pretvárat' priestor, v ktorom sa pohybuje, osvojuje si ho, privlastňuje úplne prirodzene subkultúrnym spôsobom.

Je „mestským hipíkom“", je zviazaný s urbánnym prostredím, ktoré túži „otagovat" svojou prítomnostou, a tak vyhl'adáva zabudnuté, mŕtve zóny, aby ich mohol poludštit', otlačit' do nich svoju predstavu komunitného života, v ktorom sa nemusí vzdat' svojho individuálneho postoja, svojej identity. Tú predstavu skladá z idealizovaných obrazov sveta uložených v archívoch osobnej pamäti (detstvo ako štastné obdobie kolektívneho nažívania, súdržnosti, vzájomnej podpory) i kolektívnej pamäte (napr. predstavy európskeho romantizmu a amerického transcendentalizmu idealizujúce prírodu ako možný zjednocujúci prvok modernej defragmentarizovanej spoločnosti aj identity) a transponuje ich do mestského prostredia (napríklad v podobe mobilných či komunitných záhrad). Oživuje zabudnuté miesta s tradíciou, ktoré by mohli podporit' lokálpatriotizmus, angažuje sa pri ochrane ohrozených miest vytvárajúcich, okrem iných benefitov, špecifický kolorit (napr. Trh na Žilinskej v Bratislave), podporuje komunitné spôsoby života (aktivity bratislavskej komunity Susedia na dvore). Podobne ako iné subkultúry, kmene či scény sú hipsteri charakterizovatel'ní aj prostredníctvom príznakových priestorov. Patria k nim kaviarne ako najtradičnejšie miesto stretávania, často vybavené pridanými hodnotami (čitárňou či kníhkupectvom, galériou, klubovým pódiom) a hlavne okamžite identifikovatel'ným dôrazom na štýl s prvkami recyklácie, minimalizmu, priznania nedokonalostí, vrstiev, remeselných prác, ale predsa s domáckou atmosférou a sortimentom domácich, lokálnych či aspoň fairtrade eko/bio výrobkov, ktoré podporujú iné mechanizmy výroby, distribúcie a predaja než vel'ké nadnárodné korporácie. Takým miestom môže byt' Trafačka v Nitre, pôvodne budova transformátorovej stanice usadená na

7 Charakteristika sa objaví v TV dokumente Českej televízie Kmeny, konkrétne v časti Hipsteři, v jednom zo šestnástich dokumentov, vysielaných na ČT2 od marca 2015. 
okraji obytno-sídliskovej zóny v centre mesta, dnes fotogaléria s kaviarňou. Podobne špecifickým priestorom, kam chodia v Nitre potenciálni hipsteri koketovat' so svojou subkultúrnou identitou, je Hidepark ležiaci ned'aleko Trafačky, v podstate na brehu rieky, čo vytvára ideálne prostredie pre rozširovanie aktivít (kultúrnych aj vzdelávacích). Nitranom je priestor z minulosti známy skôr ako skládka odpadu a odkalisko pre cukrovú repu z ned'alekej fabriky, takže aj v tomto prípade došlo k rekultivácii a revitalizácii nevyužitého miesta s potenciálom.

Niektorí teoretici vyčítajú hispterom, že rezignovali na politický rozmer subkultúrnej identity a dokonca ani nemožno hovorit' o estetizácii politiky, pretože im v základoch chýba akákolvek ideológia (Barker 2006; Veselý 2012b). V tomto bode je však na mieste namietat', že subkultúra nemusí byt' nutne politicky angažovaná, mala by však mat' čitatel'ný svetonázor. A ten je prítomný už v samotnej požiadavke maximálnej estetizácie životného pobytu tu a teraz s akcentom na zviditelńovanie kultúrnych pamätových stôp revitalizujúcich tradíciu. Hipster je estét, trendsetter, tvorivý brikolér (Barker 2006: 98), recyklátor, archeológ kultúrnej pamäti - kreatívny správca kultúrneho archívu. Hipster je svojím aktívnym pretváraním priestoru, v ktorom sa pohybuje, spoločensky angažovaný. Estetizácia každodennosti je jeho životný program.

Ako nekompromisný estét vracia do kultúrneho priestoru 21. storočia dandyho, ktorého pôvodne zrodilo 18. storočie ako vyvrcholenie individualizmu, „ako posledný záblesk heroizmu uprostred úpadku“, pretože, wildeovsky povedané, neexistuje nič, čo by umenie nedokázalo posvätit’ a tajomstvo života odkrýva práve umenie (Schiffer 2012: 82). Pre dandyho, milovníka pominutel'nosti, estetika stojí nad všetkým, práve ona dáva zmysel jeho existencii, pričom nevnáša do života povrchnost', ale skôr pochybnost' a odstup. Celkový výraz dandyovskej figúry Schiffer charakterizoval Wildeovým výrokom „vážnost' je kostým hlupáka, výstrednost' pod zdaním triviality, nenútenost' a l'ahostajnost' kostým mudrca" (Schiffer 2012: 21) a tento presne korešponduje s popisom habitu súčasného hipstera. Dandy je (z dnešného pohl'adu) cool, podobne ako hipster, ich postoj definuje odstup, ktorý je v rétorike ich estetických prejavov čitatel'ný ako irónia. Vysoká miera štylizácie dandyho výzoru zdôrazňuje eleganciu. Hipster je šarmantný aj ako parafráza na drevorubača, demonštruje presvedčenie, že život je v prvom rade estetická udalost'. Ak by existovala možnost', aby dandy ako individuálna figúra fungoval aj ako skupinový obraz, hipster by mohol byt jeho naplnením. Dandy však aj v tomto prípade zostáva nedosiahnutel'nou métou. A práve toto vedomie nedosiahnutel'nosti estetického ideálu posilňuje ironický postoj hipstera, pragmatického idealistu, cynického vizionára. Irónia je pohyb medzi láskou a nenávistou - voči 
sebe samému, pretože tuší, ako vel'mi je obrazom sveta, v ktorom žije i voči svetu okolo, pretože ten ho nechce pustit' z pohodlného objatia konzumu - nie je preto prekvapivé, že vo svojom okolí podnecuje analogické vášne. Hipster snažiaci sa unikat tlakom konzumu nástrojmi spotreby sa tak stáva, ako počúvame vo verejnom mediálnom priestore, ironickou pointou konzumného životného štýlu. Karel Veselý v štúdii hipstera, ktorá je súčastou projektu Kmeny skúmajúceho subkultúry v Čechách, konštatuje a zároveň sa pýta: „Ve svém měňavkovitém beztvaru jsou hipsteři dost možná definitivní postsubkulturou, která se obejde bez ideologie a i přesně vymezených hranic. Kloužou po povrchu věcí a pronásleduje je za to výsměch většiny, která v nich vidí obyčejné pozéry. Jenže co když je svět nenávidí proto, že současnému člověku západní civilizace nastavují kruté zrcadlo?" (Souček - Veselý - Vladimír 518 2011: 503). Moje doterajšie preverovanie ma však vedie k nevyhnutnému doplneniu otázky: čo všetko sa v tom zrkadle odráža? Interpretačná otvorenost' voči možným väzbám, ktoré hipster vytvára v kultúrnej pamäti, nám ukazuje omnoho plastickejší obraz, premenlivý, neohraničený, ale hlavne existenciálne ukotvený v skúsenosti až civilizačného charakteru, $\mathrm{v}$ skúsenosti permanentného dialógu medzi dvoma hodnotovými pólmi, ktoré môžu mat' v konkretizáciách rozmanitú podobu a ktoré hipster spontánne spája do skúsenostného hybridu nie nepodobného jeho ironicky hybridnému odevu. Jeho eklektická estetika „se vyznačuje častým spojováním vysokého a nízkého, vznešeného a brakového, elitního a populárního, ezoterického a exoterického“ (Daniel - Řídký 2017: 340). Takže ked' sa pýtame, čo charakterizuje súčasného hipstera a čo sa nám prostredníctvom neho ukazuje ako dobovo príznačné, odpovedáme - hodnotové napätie definovaného dynamikou protikladov:

- subjekt verzus komunita

- ultramoderné verzus starobylé

- originalita/novost'/zmena a tradícia/stabilita

- mesto verzus vidiek

- kozmopolitizmus verzus túžba po koreňoch a nostalgia za domovom

- lokálne verzus globálne

- zábava verzus práca

- programové outsiderstvo a kultúrne insiderstvo.

Vo výsledku môže toto vnútorné napätie pôsobit' ako ambivalentné či dokonca sémanticky nezretel'né až rozporuplné, hipster však chce tlmočit' možnú zlučitel'nost' protikladov, sprítomňuje chronotopy čiastočnej konklúzie, preto je jeho estetika ironická, nedemonštruje odmietanie, nevyvoláva pobúrenie. 
Lifestylová TV show Herbář je mediálnou udalostou, ktorá dokazuje, že syntéza, v ktorej hipsterská subkultúra revitalizuje mainstream, už prebieha. Od roku 2013 Česká televízia vysiela Herbár (s podtitulom originálny a $100 \%$ prírodný), o ktorom jeho dramaturgička pri piatej sérii vyhlásila, že sa stal originálnym živým trendom (http://www.ceskatelevize.cz/porady/10614805433-herbar/). Hoci subkultúrna väzba relácie nikdy nie je priamo priznaná, od prvej časti má divák neodbytný a nakoniec aj zdokumentovatel'ný pocit, že sleduje príkladnú hipsterskú šou. Ked' sa v 4. časti 1. série moderátorka (neskôr aj spoluscenáristka) Kateřina Winterová stažuje moderátorke Linde Rybovej, že musí zohl'adňovat' mainstreamové publikum a nemôže vyrábat' zeleninové štavy, nepriamo tým priznáva lifestylovú príslušnost'. Aj samotná sémantika názvu je velavravná: herbár nie je len atlasom liečivých rastlín, má rozmer uchovávania tradície, generačného poznania a vlastnej práce, zbierania a archivácie. Sušená bylina v ňom nie je len liečivkou či korením, ale aj autentickým sprítomnením neprítomného. Seriál má láskavo ironickú rétoriku, využíva pri tom generačné narážky (len hipster je ochotný priznat' sa, že v mladosti žral Petra Nagya a povýšit' niečo také vytesnené na cool skúsenost', ako to robia moderátorky v 3. časti 1. série), narážky na rodové stereotypy, priatel'ské hašterenie, prekáranie a naoko vyvolaný konflikt. Jeho videoklipová estetika často spája nesúrodé prvky popovej piesne a vidieckej idyly, semiotika módy je nesmierne dynamická, rozmanitá a tvorivo odvážna, predstavuje kostýmy tradičné, viazané na folklór, ale aj ultra moderné, alternatívne dizajnérske kúsky, či retro outfity. Linda Rybová priznáva, že jej netere sledujú seriál kvôli tomu, ako je urobený a nie kvôli tomu, o čom hovorí, hoci jeho témy sú $100 \%$ hipsterské: moderné, teda trvalo udržatel'né Čechy, elektromobily, oživovanie tradícií, rodina, domáca výroba, regionálne potraviny, bio kvalita, ekologické hospodárenie, chutná zdravá kuchyňa so sezónnymi potravinami a medzinárodnými inšpiráciami... vždy v absolútne štýlovom balení. S „Lindou a Kačenou“ ešte aj drina na záhrade vyzerá ako štýlová zábava.

Od hipstera k hippies - usádzanie nových subkultúrnych dominánt

Dynamika, v ktorej v 60. rokoch 20. storočia hippie pohltil hipstera, sa ukazuje byt' stále živá, dokonca $\mathrm{v}$ jednej z aktuálnych podôb hipstera rezonuje intenzívnejšie a „vracia“ ho spät k hippiemu, či možno posúva k jeho novodobej verzii. Nie náhodou oxymoronicky spájam motív návratu a novodobý obraz ako pohyb dopredu. $\mathrm{V}$ tejto návratno-revitalizačnej dynamike sa totiž skutočne rodí staronový typ kultúrnej society, ktorý 
spája individualizačné prvky moderného hipsterstva a komunitné cítenie pôvodnej hippies subkultúry. Nechcem tým tvrdit', že 60. roky 20. storočia sú úplne nepoznačené filozofiou individualizácie, ved' samotní hippies na niekol'kých úrovniach svojho životného štýlu potvrdzovali rešpekt k subjektu. Ich bytostnou súčastou boli otvorenost' voči inokultúrnej odlišnosti, filozofia transcendentalistov sústredená na sebadôveru (Ralph Waldo Emerson) či občiansku neposlušnost' ako dôkaz zvrchovanosti individuálneho svedomia (Henry David Thoreau), odkazujúca na filozofické tradície vzostupu subjektu, ako ich rozkrýva napríklad americký filozof Robert C. Solomon (1996) vo svojom diskurzívnom čítaní dejín európskeho myslenia.

Hippies inšpirujúce teoretické ideály transcendentalizmu, ktoré požadovali priestor pre individuálny rozvoj v prostredí komunitného života rešpektujúceho zvrchovanost prírody, sa začiatkom 40. rokov 19. storočia snažili v Massachusetts realizovat' A. B. Alcott v extrémne utopickom projekte agrárnej komunity Fruitlands či manželia Ripleyovci na tzv. Brook Farm Institute of Agriculture and Education ned'aleko Bostonu. Komunita Fruitlands, založená v roku 1840, fungovala len asi 7 mesiacov, Brook Farm, neskôr aplikujúca Fourierov sociálny model, skončila v roku 1847 a nás dnes môže tešit', že aktuálna slovenská Zaježová má za sebou niekol'konásobne dlhší čas úspešnej existencie než jej americkí predchodcovia.

Zaježová (http://www.zajezka.sk/sk) je projekt, ktorého podoba sa bez prerušenia formuje od polovice 90 . rokov minulého storočia. Vznikom ekokomunity Sekier dochádza k prvým, ešte nezámerným revitalizačným krokom vyprázdňujúceho sa regiónu. L'udí unikajúcich z miest s ambíciou vytvorit' si na lazoch podmienky na prirodzenejší, jednoduchší život v súlade s prírodou a ideálne aj na ekonomickú nezávislost' by sme skôr stotožnili s novodobými hippies než hipstermi. Tých začala Zaježová lákat' až v druhej vlne, teda v posledných rokoch, ked' rozšírila svoje prioritne vzdelávacie aktivity. Činnost Živice, vzdelávacieho centra, Sokratovho inštitútu, kurzy l'udových remesiel prilákali „alternatívne zmýšl'ajúcich ludí", ako priznávajú aj na webových stránkach Zaježky (http://www.zajezka.sk/ sk/blog/star\%C3\%BD-svet-v-novom), ktorí sa rozhodli bránit' konzumnému životnému štýlu radikálnejšie a azda trocha romanticky veria v ochranné štíty prírodného sveta, hoci spolu s nimi prichádzajú aj podnety a aktivity napríklad na zlepšenie sociálnej vybavenosti. Zaježka je otvorená komunita a hipster má v sebe čosi z moderného nomáda, dušou je zvedavým kozmopolitom, ktorému záleží na mieste, $\mathrm{v}$ ktorom aktuálne žije, a preto v ňom stopu rozhodne zanechá, len zatial' ešte nie je zrejmé, akú bude mat' intenzitu a podobu. Posilnenie hippies hodnôt rozhodne obraz hipstera koriguje a pravdepodobne mení aj dominanty jeho životného štýlu, čo môže byt' d'alším dôkazom rozpúštania pôvodnej subkultúrnej identity. 
Na záver...

... by sa žiadala pointa, zhrnutie, významná sémantická bodka. Preto využijem benefity kruhového rámcovania a vrátim sa na začiatok, k motivácii, v ktorej vyslovujem ambíciu identifikovat'hipsterovo aktuálne miesto v kultúrnej pamäti v možných pozitívnych väzbách na tie elementy kultúrnej tradície, ktoréfungujú stabilizačne, ako aj čo najpresnejšie pomenovat'tie kvality, ktoré by aj napriek permanentným obsahovým zmenám hipsterského kódu vystihovali jeho integritu. Napriek rozplývavosti, nejasným a stále meniacim sa kontúram aktuálneho obrazu hipstera, sa mi ukazujú niektoré konštitutívne elementy estetického kódu ako pozitívne identifikovatelné a pomerne stabilné: estetickékultivovanie seba a chronotopov každodennosti v duchu dandyovských ideálov, ironický postoj nie ako vkusový súd, ale svetonázor - obranné gesto, opatrnost', zachovanie estetickej dištancie vyjadrené cool postojom a predovšetkým hodnotové napätie definovanédynamikou protikladov. Zastrešit ich môžu subjekt verzus komunita, originalita/novost' až ultramodernost'/zmena verzus tradícia/starobylost'/ stabilita, kozmopolitizmus verzus túžba po koreňoch/nostalgia za domovom, mesto verzus vidiek, lokálne verzus globálne, zábava verzus práca, programové outsiderstvo verzus kultúrne insiderstvo, ktoré v dynamickej zmene pozícií zahŕňa aj napätie medzi vysokým a nízkym či elitárskym a popkultúrnym.

Spomínaná neuchopitel'nost' a rozplývavost' tak môžu byt' aj prirodzenou reakciou na formalizovanie, či dokonca sémantické a hodnotové vyprázdňovanie identifikačných prvkov hipsterskej identity v kultúrnom dialógu časom prirodzene osvojených dominantnou kultúrou. Hipsterská nostalgia milovníka vel'komesta za úprimnostou a tradíciami vidieka (nech sú akokolvek iluzívne), komunitné záhrady uprostred vel'komiest, dôraz na ekologické hospodárstvo a biokvalitu potravín, nadšenie pre zdravý životný štýl prenikajúce zo subkultúrnych okrajov do mainstreamu, zdiel'ané nadšenie z vymožeností nových technológií a rozšírenie sociálneho priestoru bez ochoty vzdat' sa tradičnej l'udskej interakcie sú aktuálne dôkazom, že niektoré z hipsterských ideálov budú pravdepodobne životaschopné v dlhodobej perspektíve. A azda aj práve preto, že dominantná kultúra v rámci svojej heterogénnosti tak nekonfliktne (hoci často s ironickým úšklabkom) vstrebáva príznakové dominanty životného štýlu pôvodne elitárskeho hipstera, sa nám môže zdat', že jeho špecifickost' vlastne neexistuje a hipstermi sa v mnohých životných postojoch stali mnohí z nás, subkultúrne indiferentných členov kultúrneho spoločenstva.

Fanuár 2019 


\section{Bibliografia}

Assmann, Jan. 2001. Kultura a pamèt'. Praha: Obzor.

Barker, Chris, 2006. Slovník kulturálních studií. Praha: Portál.

Bauman, Zygmunt. 1995. Úvahy o postmoderní době. Praha: Slon.

Bauman, Zygmunt. 2002. Tekutá modernita. Praha: Mladá fronta.

Biller, Stanislav. 2015. Proč vymřeli hipsteři? Marianne 9: 109-111.

Bollason, Atli. 2012. Confession of a Hipster. [2017-06-03] Dostupné z:

https://grapevine.is/mag/column-opinion/2012/08/03/confessions-of-a-hipster/.

Daniel, Ondřej - Řídký, Josef. 2017. Nová „letenská šlechta“? Hipsteři, jejich paradoxy a ironie jedné ironie. In: Bílek, Petr A. - Šebek, Josef (eds.): Česká populární kultura. Transfery, transponování a dalši tranzitní procesy. Praha: Univerzita Karlova: 322-349.

Feranec, Daniel. 2015. Desatkrát: Hipsteri neexistujú. [2017-11-28] Dostupné z: https://dennikn.sk/blog/115873/desatkrat-hipsteri-neexistuju/.

Havlín, Tomáš. 2012a. V městě zaslíbeném. [2017-11-22] Dostupné z: http://novyprostor.cz/clanky/396/v-meste-zaslibenem.

Havlín, Tomáš. 2012b. Komunita hypu. [2017-11-22] Dostupné z: http:// novyprostor.cz/clanky/396/komunita-hypu.

Heath, Joseph - Potter, Andrew. 2012. Kup si svou revoltu. Praha: Rybka Publishers.

Hebdige, Dick. 2012. Subkultura a styl. Praha: Dauphin.

Hassan, Ihab. 1987. The Postmodern Turn: Essays in Postmodern Theory and Culture. Ohio: Ohio State University Press.

Hubík, Stanislav. 1991. Postmoderná kultúra. Úvod do problematiky. Olomouc: Mladé umění $\mathrm{k}$ lidem.

Chorvát, Ivan. 2015. Premeny životného štýlu - sociologické východiská a predpoklady. [2017-09-02] Dostupné z: https://www.sav.sk/journals/ uploads/03301203Chorvat\%20OK.pdf.

Istok, Michaela. 2013. Praktický slovníček bratislavského hipstera. [2015-0722] Dostupné z: https://mimivofinsku.wordpress.com/2013/08/20/ prakticky-slovnicek-bratislavskeho-hipstera/.

Kapusta, David. 2012. Fenomén hipster alebo ako sa stat'hipsterom. [2017-1110] Dostupné z: https://davidkapusta.blog.sme.sk/c/312165/fenomen-hipster-alebo-ako-sa-stat-hipsterom.html.

Klein, Naomi. 2000. Bez loga. Praha: Argo.

Lipovetsky, Gilles. 2002. Říse pomíjivosti. Móda a její úděl v moderních společnostech. Praha: Prostor.

Lipovetsky, Gilles. 2007. Paradoxní štěstí. Esej o hyperkonzumní společnosti. Praha: Prostor. 
Lotman, Jurij M. 1994. Text a kultúra. Bratislava: Archa.

Mailer, Norman. 1990. Bílej negr. Povrchní reflexe na hipstera. Vokno 20: 74-83.

McCleary, John Bassett. 2010. Hippie encyklopedie. Praha: Volvox Globator.

Malíčková, Michaela a kol. 2015. Praktická estetika 8: O interpretácii popkultúrneho diela. Nitra: UKF.

Overstreet, Martina. 2017. Co se vám stalo, hipsteři? Elle 10: 41-42.

Plesník, Lubomír a kol. 2008. Tezaurus estetických výrazových kvalít. Nitra: UKF.

Schiffer, Daniel Salvatore. 2012. Dandysmus, poslední záblesk heroismu. Praha: Karolinum.

Solomon, Robert C. 1996. Vzostup a pád subjektu. Nitra: Enigma.

Souček, Tomáš - Veselý, Karel - Vladimír 518. 2011. Kmeny. Současné městské subkultury. Praha: Biggboss.

Šabík, Vincent. 1996. K transformácii dialektiky kultúry a subkultúry.

In: Výrazové osobitosti teenagerskej kultúry. O interpretácii umeleckého textu 17. Nitra: VŠPg:

Tracy, Thomas. 2017. Sloupek Thomase Tracyho. Cafe Journal 20: 1-2.

Veselý, Karel. 2012a. Děti konzumního ráje. [2017-11-22] Dostupné z: http://novyprostor.cz/clanky/396/deti-konzumniho-raje.

Veselý, Karel. 2012b. Co prijje po ironii. [2017-11-22] Dostupné z: http:// novyprostor.cz/clanky/396/co-prijde-po-ironii.

Waldenfels, Bernhard. 1998. Znepokojivá zkušenost cizího. Praha: OIKOYMENH.

Welsch, Wolfgang.1993. Estetické myslenie. Bratislava: Archa.

Žilka, Tibor. 2000. Postmoderná semiotika textu. Nitra: UKF. 